УДК 352.07(477-21)

DOI: https://doi.org/10.26642/jen-2019-3(89)-178-183

Н.О. Руденко, магістрант

Державний університет «Житомирська політехніка»

\title{
Розвиток Коростишівської міської об’сднаної територіальної громади в умовах децентралізації влади
}

\author{
(Представлено Бражевським В.М.)
}

У статті розглянуто стан розвитку Короститівської міської об'єднаної територіальної громади в умовах децентралізації влади. Запропоновано та проаналізовані основні напрями реформування системи місиевого самоврядування на прикладі Короститівської ОТГ. Проаналізовано перші підсумки сочіально-економічного розвитку Коростишівської міської об'єднаної територіальної громади після проведення реформи децентралізації влади. Визначено основні проблеми, изілі, напрями, завдання та заходи, спрямовані на досягнення розвитку ОТГ. Запропоновано напрями покращчання функціонування Коростишівської міської об'єднаної територіальної громади в умовах децентралізачії влади на сучасному етапі розвитку. Доведено важливість запровадження реформи з децентралізації влади на иляху розвитку Коростишівської ОТГ та визначено переваги децентралізованого управління. Розглянуто питання організації та функціонування органів місиевого самоврядування та місцевих державних адміністрацій, їх взаємодія і проблеми розмежування повноважень. Виокремлено основні елементи, які впливають на розвиток місиевого самоврядування. Встановлено, щзо основою нової системи місиевого самоврядування в Україні мають стати об'єднані територіальні громади, щзо утворюються на добровільній основі за законодавчо визначеною прочедурою та самостійно за рахунок власних ресурсів вирішуватимуть питання місцевого значення. Визначено, щуо головною метою розвитку Коростишівської міської об’єднаної територіальної громади є підвищення якості життя населення шляхом реалізації стратегічного курсу на досягнення економічного та соціального самодостатку. Зроблено висновок, щчо процес децентралізації потребує комплексної роботи компетентних осіб та усвідомлення територіальною громадою своїх можливостей на місиях.

Ключові слова: місцеве самоврядування; децентралізація; територіальна громада; територіальний розвиток.

Актуальність теми. Однією з найвагоміших реформ, розпочатих в Україні протягом останніх років, $\epsilon$, безперечно, реформа $з$ децентралізації влади. У 2015 році відбувся справжній прорив у цьому напрямі. Відповідною реформою скористалася Коростишівська міська рада, внаслідок чого в грудні 2016 року утворилася Коростишівська міська об'єднана територіальна громада (ОТГ). На місцевих виборах обрано депутатів, голову, проведено децентралізацію фінансів. Населення ОТГ склало - 30615 осіб, об'єдналися 10 рад та 29 населених пунктів, площею 429,79 км². Для завершення процесу децентралізації необхідно не лише внести зміни в нормативно-правові акти та забезпечити їх реалізацію центральними органами виконавчої влади, але й провести значний обсяг роботи самою об'єднаною територіальною громадою на місці, адже органи місцевого самоврядування мають надавати весь комплекс необхідних послуг для життєзабезпечення населення громади.

Аналіз останніх досліджень і публікацій. Дослідження місцевого самоврядування проводяться в різних напрямах. Зокрема, становлення та розвиток місцевого самоврядування вивчають Т.Астапова [8], О.Гордєєв [3] та Б.Лис [5]. У працях описано історію утворення українського самоврядування. Особливості децентралізації в Україні досліджують С.Серьогін [6], Н.Гончарук [6], І.Ярошенко [7], І.Семигуліна [7]. У працях висвітлюється проблематика процесу утворення громад, його особливості в Україні та досвід процесу децентралізації за кордоном.

Мета статті - визначити напрям розвитку Коростишівської міської об’єднаної територіальної громади та основні проблеми місцевого самоврядування у громаді на сьогодні.

Викладення основного матеріалу дослідження. Значним поштовхом для демократизації суспільства стало закріплення статусу місцевого самоврядування на конституційному рівні, а саме стаття 7 Конституції України визначає, що в Україні місцеве самоврядування визнається та гарантується. Самоврядуванню присвячений також і ХІ розділ КУ. На основі конституційних норм був прийнятий ЗУ «Про місцеве самоврядування в Україні» [6], і цю сферу законодавства суттєво наблизила до європейських стандартів ратифікація Свропейської хартії [6]. Теоретично в умовах закріплених багатьох прав і свобод законодавчо місцеве самоврядування має грунтовну правову основу для розвитку та всебічного функціонування самоврядування. Однак на практиці виникає безліч колізій, які, в свою чергу, є джерелом суперечностей між суб'єктами публічних правовідносин. А пересічні учасники місцевих громад не 
зацікавлені в цьому, бо численні питання місцевого рівня не вирішуються, а лише перекидаються з однієї компетенції в іншу. Оскільки така проблема є не локальною, то вона має «пандемічний» характер хвороби регіонів нашої держави.

Сучасний етап побудови демократичної, соціально-правової держави з врахуванням глобальних змін неможливий без реорганізації системи місцевого самоврядування.

Реформування місцевого самоврядування ставилося на обговорення не один рік. Це відбувалося на усіх рівнях влади, однак будь-які спроби втілити реформування досі не були успішними. Децентралізація та прозорість діяльності органів місцевого самоврядування сьогодні вже вийшла за межі звичайного бажання покращити публічне управління, а стала гострою необхідністю та передумовою виходу з кризи в Україні. На початку 2015 року було прийнято Стратегію сталого розвитку «Україна-2020».

В умовах децентралізації Коростишівська міська об'єднана територіальна громада отримала широкі повноваження і ресурси. Щоб використати їх ефективно, потрібна якісна місцева стратегія розвитку і чіткий план іiі реалізації. Керівництво міської об’єднаної територіальної громади розуміє свою відповідальність за майбутнє громади, тому намагається не лише «латати діри», а підходити до розвитку ОТГ стратегічно.

Кожен орган місцевого самоврядування, який увійшов до складу ОТГ, до об’єднання мав власні пріоритети розвитку та власну систему цінностей щодо управління ресурсами. Після об'єднання ці пріоритети очевидно мають бути переглянуті та повинні виробитися підходи до управління «об'єднаними» ресурсами:

1. Потреба ефективного управління новими земельними, бюджетними ресурсами, які стали доступними для ОТГ, і можуть бути використані для розвитку; ОТГ.

2. Збільшення кількості зацікавлених сторін, з якими потрібно узгоджувати прийняття рішень у межах

У більш широкому контексті Коростишівська міська об'єднана територіальна громада має ефективно відповідати зовнішнім викликам, таким як глобалізація економіки, підвищення мобільності трудових ресурсів та з ними пов'язаними росту безробіття, посиленню міжнародної конкуренції за інвестиції та ресурси розвитку.

Відповіддю на ці та деякі інші виклики може стати перспективне (середньо- та довгострокове) планування ОТГ. У цьому контексті важливим $є$ не тільки (і не стільки) результат, скільки сам процес його створення за участі широкого кола зацікавлених сторін - представників різних населених пунктів, різних підприємств, установ та організацій, різних політичних поглядів.

Коростишівська громада була відібрана в числі 10 ОТГ для участі в проекті «Сприяння стратегічному розвитку територіальних громад малих міст», що реалізується Асоціацією міст України спільно з GIZ (Джі Ай Зет). В межах проекту призначено експерта з розробки стратегічних документів, за допомогою якого ведеться розробка Стратегії розвитку Коростишівської міської об'єднаної територіальної громади на період до 2027 року.

Проаналізувавши перші підсумки соціально-економічного розвитку Коростишівської міської об’єднаної територіальної громади після проведення реформи децентралізації влади, необхідно наголосити на показниках місцевого бюджету. Крім доходів, що отримував бюджет до об'єднання, зараз до бюджету зараховується 60 \% податку на доходи фізичних осіб. У перший рік після об'єднання дохідна частина міського бюджету, за рахунок ПДФО, збільшилася на 39,5 млн грн;

- у 2018 році цей показник становив 47,7 млн грн;

- планові показники 2019 року становлять 52,4 млн грн.

В цілому власні надходження до бюджету збільшилися у 4 рази, що становить 93,7 млн грн.

У 2018 році бюджет Коростишівської громади отримав в загальному 109,5 млн грн трансфертів 3 державного бюджету, що на 28,2 млн грн більше ніж у 2017 році.

Одночасно зі збільшенням дохідної частини пропорційно зростає і видаткова частина.

Варто зауважити, що кореляція між дохідною та видатковою частиною бюджету є досить слабкою. Передані (делеговані) видатки державним бюджетом недостатньо враховують фінансовий ресурс бюджету, а інколи взагалі не підкріплені таким ресурсом. Так протягом 2017 та 2018 років міським бюджетом профінансовано видатки, які визначені функціями держави в сумі 6,4 млн грн; виділено фінансування для підтримки районних установ в сумі 5,3 млн грн; профінансовано пільгове перевезення громадян на загальну суму 2,4 млн грн.

3 державного на регіональний і місцевий рівні передаються окремі заклади в освітній, медичній та культурній сферах.

Складні непрозорі схеми поділу фінансових ресурсів є показником загальнодержавної політики централізації. Тобто, прибуткові сфери віддаються під крило центральної державної влади, а на місцеве самоврядування покладається «тягар» підтримання соціальної сфери, яка, зрозуміло, є неприбутковою. При цьому самоврядування зазвичай має недостатність фінансування цієї сфери, що незворотньо веде до 
застою та погіршення освіти, культури та охорони здоров'я не тільки на регіональному рівні, але і на державному в цілому [8].

Дотацією з місцевого бюджету на здійснення переданих з державного бюджету видатків 3 утримання закладів освіти та охорони здоров'я, за рахунок відповідної додаткової дотації з державного бюджету у 2018 році, Коростишівській ОТГ передбачено кошти у сумі майже 10,8 млн грн, у 2019 році - в сумі 8,3 млн грн, яких недостатньо для повного забезпечення повноважень делегованих державою. Незабезпеченість становить 3,35 млн грн у 2018 році та 6,8 млн грн у 2019 році.

Створений дефіцит на зазначену вище суму були змушені покрити за рахунок власних коштів, тим самим скоротивши бюджетні призначення на суспільно важливі програми та проекти, які мали б забезпечити процеси розширеного відтворення громади.

Основні реалізовані проекти у 2017-2018 роках:

За рахунок коштів Державного фонду регіонального розвитку проведено реконструкцію будівлі по вул. Київській, 53 під приміщення для закладу позашкільної освіти (Будинок дитячої творчості). Вартість проекту - 5,2 млн грн (співфінансування з міського бюджету - майже 2,0 млн грн).

За рахунок субвенції на формування інфраструктури ОТГ:

- закуплено 2 транспортні засоби спеціального призначення МАЗ (1 з піскорозкидальним та плужнощіточним обладнанням та 1 самоскид зі снігоочисним відвалом) - 4,0 млн грн;

- виготовлено містобудівну документацію (топографічні, генеральні плани та плани зонування) населених пунктів старостинських округів Коростишівської міської ради - 1,8 млн грн;

- закуплено міні-навантажувач AVANT з навісним обладнанням - 1,5 млн грн;

- закуплено трактор з навісним обладнанням вартістю - 616,0 тис. грн;

- проведено реконструкцію освітлення по вул. Центральній та вул. Рад у с. Більківці та здійснено капітальний ремонт освітлення по вул. Київській в м. Коростишеві - 220,2 тис. грн.

За рахунок коштів Фонду соціально-економічного розвитку окремих територій:

- проведено реконструкцію даху і будівлі шляхом часткової термосанації (заміна вікон) Коростишівського НВК школа-ліцей ім. Л.Х. Дарбіняна - 1,1 млн грн;

- відкрито Більковецький заклад дошкільної освіти (дошкільною освітою охоплено 20 дітей);

- здійснюється спорудження 2-х багатофункціональних спортивних майданчиків зі штучним покриттям на базі стадіону «Шахтар» та Коростишівського НВК школа-ліцей ім. Л.Х. Дарбіняна (вартість кожного 1,5 млн грн).

За рахунок коштів місцевого бюджету:

- розпочато будівництво господарського блоку ДНЗ № 10 по вул. Семінарській, 68 у м. Коростишеві, вартість проекту становить 8,4 млн грн (3,0 млн грн. направлено у 2018 році).

- проводиться капітальний ремонт частини приміщень ДНЗ ясла-садок № 13 «Ялинка» вартістю 2,2 млн грн.

В перспективі, на 2019-2021 роки, Коростишівська ОТГ планує реалізувати проекти у таких сферах:

1. Проекти житлово-комунального господарства;

2. Інфраструктурні проекти;

3. Проекти соціальної сфер;

4. Приватні інвестиційні проекти.

Коростишівська громада бере участь у проектах, що фінансуються європейськими організаціями ULEAD (Юлід) та Німецьким товариством міжнародного співробітництва GIZ (Джі Ай Зет).

Також Коростишівська ОТГ була відібрана в числі 30 громад для участі в проекті «Енергоефективність у громадах II», що впроваджується організацією GIZ (Джі Ай Зет). В межах якого Коростишівська громада приєднується до європейської ініціативи «Угода мерів» 3 метою впровадження на своїй території енергоефективних заходів та скорочення викидів $\mathrm{CO}_{2}$ на 30 \% до 2030 року.

У процесі реформи децентралізації виникає декілька головних проблем, серед яких можна назвати:

1. Непослідовність нормативного забезпечення. Неприйняті зміни до Конституції, що «підвішує» прийняття багатьох важливих нормативних актів;

2. Нові кадри, нестача знань, брак відповідальності. До Коростишівської міської об'єднаної територіальної громади прийшло багато активних, хороших людей, які є новачками у владі та потребують знань «з нуля». Та й для досвідчених представників самоврядування, які опинилися в нових умовах, навчання та консультативна допомога не будуть зайвими.

На сьогодні не врегульовано питання розподілу повноважень між органами місцевого самоврядування та органами виконавчої влади в цілому, а також функцій та повноважень між місцевими радами ОТГ та районними державними адміністраціями й районними радами.

У межах реформи необхідно чітко визначити повноваження, які залишаються за райдержадміністрацією та райрадою, переглянути чисельність та відповідно видатки на утримання їхніх апаратів. 
Враховуючи високі ризики корупційних дій щодо використання бюджетних коштів, актуальним $\epsilon$ питання запровадження механізмів контролю за діяльністю органів місцевого самоврядування як з боку державних органів, так і з боку громадськості.

В умовах бюджетної децентралізації є потреба здійснення належного контролю за роботою органів влади різних рівнів при плануванні та виконанні ними бюджетів, управлінні і використанні фінансових ресурсів.

Для вирішення цієї проблеми потрібно:

1. Забезпечити ефективний попередній та поточний держфінконтроль за їх діяльністю;

2. Налагодити максимально прозору діяльність місцевих органів влади та іiі контроль 3 боку громадськості.

Тепер саме від нас із вами залежить, чи реалізує громада свій потенціал та як буде жити далі.

Часто відбувається так, що питання, які мають вирішуватися тільки органами місцевого самоврядування, розглядаються державною адміністрацією. А ось самоврядуванню за допомогою безлічі норм, інструкцій, постанов виконавчої влади нав'язуються ресурсозатратні та неприбуткові об'єкти та зобов'язання, що їх потрібно утримувати, при цьому без належної фінансової та матеріальної бази. Також, порівнявши згадані вище закони (ст. 13 ч. 1 п. 2 3У «Про місцеві державні адміністрації» та ст. 27 п. 13 У «Про місцеве самоврядування») не важко помітити, що галузь соціально-економічного розвитку теж $\epsilon$ юрисдикцією обох органів [1;2; 4].

Відповідно до Методики формування спроможних територіальних громад, територіальна громада має забезпечити виконання економічної, соціальної та екологічної функцій [9]. Для закріплення позитивних тенденцій та вирішення проблемних питань економічного і соціального розвитку територіальної громади, координації роботи органів виконавчої влади, місцевого самоврядування, комунальних підприємств розроблено Програму економічного і соціального розвитку Коростишівської об'єднаної територіальної громади на 2019 рік.

Методологічною основою та законодавчим підгрунтям розроблення Програми є наказ Мінрегіону від 30.03.2016 року № 75 «Про затвердження методичних рекомендацій щодо формування і реалізації прогнозних та програмних документів соціально-економічного розвитку об'єднаної територіальної громади» [10], законів України «Про державне прогнозування та розроблення програм економічного і соціального розвитку України», «Про місцеве самоврядування в Україні», бюджетного законодавства на основі результатів аналізу проблем та першочергових потреб громадян, які проживають на території об’єднаної територіальної громади.

Метою Програми є узгодження спільних дій органу місцевого самоврядування та суб'єктів господарювання різних форм власності по створенню сприятливих умов для забезпечення соціальноекономічного розвитку громади.

Відповідно до оцінки тенденцій економічного і соціального розвитку Коростишівської об'єднаної територіальної громади та наявних проблем, у Програмі визначено цілі, завдання економічної та соціальної політики на 2019 рік.

Визначені цілі та завдання економічної, соціальної політики населених пунктів територіальної громади на 2019 рік спрямовані на розвиток об'єднаної територіальної роботи 3 благоустрою, виконання ремонтних робіт на об'єктах комунальної власності, наповнення дохідної частини бюджету, 3 метою формування якісного та безпечного середовища життєдіяльності населення об'єднаної територіальної громади.

Проаналізувавши стан справ по галузях та врахувавши проблемні питання, були сформовані цілі та пріоритети соціально-економічного розвитку об'єднаної територіальної громади на 2019 рік.

Основними напрямами Програми є:

1. Забезпечення зростання дохідної частини бюджету ОТГ та підвищення ефективності використання бюджетних коштів;

2. Ефективне використання земельних ресурсів громади та об'єктів комунальної власності громади;

3. Сприяння створенню привабливого інвестиційного клімату територіальної громади шляхом реалізації інвестиційних проектів, спрямованих на соціально-економічний розвиток;

4. Покращення якості житлово-комунальних послуг, санітарно-екологічного стану та благоустрій ОТГ;

5. Забезпечення функціонування на належному рівні соціальної та гуманітарної сфери, подальший розвиток дошкільної та позашкільної освіти;

6. Підвищення безпеки життєдіяльності населення.

Успішне виконання Програми забезпечить:

1. Наповнюваність місцевого бюджету, проведення раціональної та ефективної бюджетної політики, дотримання фінансової дисципліни, підвищення результативності бюджетних видатків;

2. Підвищення стандартів життя;

3. Створення комфортного для проживання середовища. 
Головна мета розвитку громади у 2019 році є підвищення якості життя населення шляхом реалізації стратегічного курсу на досягнення економічного та соціального самодостатку.

У 2019 році обов'язковою умовою є:

1. Збалансування доходів та видатків бюджету;

2. Збереження обсягів надходження доходів до місцевого бюджету;

3. Використання додаткового фінансового ресурсу таким чином, щоб отримати максимальний економічний ефект і вирішити найбільш нагальні та важливі завдання;

4. Визначення пріоритетних проектів розвитку, фінансування яких здійснюватиметься за бюджетні кошти (бюджетні кошти мають витрачатися на проекти та програми, які нададуть найбільший економічний чи соціальний ефект).

Взаємопов'язані завдання та заходи спрямовані на досягнення цілей розвитку ОТГ та очікувані результати їх виконання.

Враховуючи проектний підхід до вирішення проблем ОТГ, ці завдання конкретизовані в розрізі визначених пріоритетів і завдань, діючими та перспективними проектами ОТГ з визначенням джерел фінансування кожного проекту.

Джерелами фінансування проектів соціально-економічного розвитку ОТГ є кошти Державного, обласного та місцевого бюджету, коштів підприємств, інвесторів, спонсорської допомоги та інших джерел, не заборонених законодавством України, які спрямовані на соціально-економічний розвиток інфраструктури об'єднаної територіальної громади.

Говорячи про розвиток Коростишівської міської об’єднаної територіальної громади, слід зауважити про позитивні зрушення, які очевидні: відбудовані дороги, відремонтовано дитсадки і школи, осучаснюються медзаклади, розвивається інфраструктура, починає поширюватися підприємництво в селах, яке дає можливості ефективно використовувати місцеві ресурси. Впровадження децентралізації та залучення додаткового фінансування від інвесторів виявляє ефективних менеджерів на місцях, здатних вдало скористатися новими можливостями та спрямувати кошти в потрібне русло. Це підвищує довіру людей до місцевої влади та до представників великого бізнесу, які не лише забезпечують людей роботою, а й сплачують податки до бюджету на потреби громади. Робити певні висновки про успіх реформи поки ще зарано, але перші кроки показують позитивну динаміку, здатну відродити українське село і зрівняти його в можливостях з містом.

Отже, серед основних напрямків розвитку Коростишівської міської об'єднаної територіальної громади можна назвати розробку Стратегії розвитку Коростишівської міської об'єднаної територіальної громади на період до 2027 року. Вказана Стратегія спрямована на розвиток Коростишівської об'єднаної територіальної громади, створення сприятливого середовища для впровадження децентралізаційної реформи, зміцнення місцевого самоврядування та зрештою успішної громади. Стратегія розвитку Коростишівської громади на період до 2027 року, яка базується на чинному законодавстві, методології СС, кращій практиці інших громад України та спрямована на забезпечення подальшого розвитку. Мета та завдання - перетворити Коростишівську громаду у регіон, що демонструватиме сталий економічний розвиток, зростання багатогалузевої промисловості та сільського господарства, посилення конкурентних позицій з безпечними умовами проживання, у якому кожен громадянин матиме умови для розвитку та підвищення стандартів життя.

Місцевий бюджет володіє ресурсною базою, яка була значно більша. Робиться все можливе, щоб нові можливості були максимально ефективно реалізовані. У Коростишівській міській об'єднаній територіальній громаді $є$ низка преференцій і додаткових можливостей, якими важливо скористатися.

Об’єднуючись, долаючи певні перешкоди на початку, громада, тим не менше, закладає важливі основи для свого економічного розвитку в перспективі, бо отримує територіальні, земельні, демографічні ресурси, маючи змогу облаштувати інфраструктуру.

Висновки. Коростишівська міська об’єднана територіальна громада знаходиться у стані початкового розвитку. Необхідна загальна мобілізація та публічна підтримка реформи децентралізації не тільки з боку усіх політичних сил, а також пересічних громадян. Така консолідація позитивно вплине на розвиток місцевого самоврядування та розвиток громади в цілому. Таким чином, слід зазначити, що децентралізація - це запорука ефективного територіального розвитку, шлях до демократизації, дійсного народовладдя.

\section{Список використаної літератури:}

1. Про місцеве самоврядування в Україні : Закон України від 07.05.2017 № 24 / Відомості Верховної Ради України [Електронний ресурс]. - Режим доступу : rada.gov.ua.

2. Про місцеві державні адміністрації : Закон Україн № 586-XIV / Відомості Верховної Ради України [Електронний ресурс]. - Режим доступу : rada.gov.ua. 
3. Гордєєв О.К. Забезпечення сталого місцевого розвитку: підходи, принципи, складові / О.К. Гордєєв // Державне будівництво. - 2012. - № 2 [Електронний ресурс]. - Режим доступу : http://www.kbuapa.kharkov.ua/e-book/db/2012-2/doc/4/04.pdf.

4. Забезпечення системного підходу до реформування адміністративно-територіального устрою [Електронний pecypc]. - Режим доступу : http://www.niss.gov.ua/public/File/2015_analit/reformaATU.pdf.

5. Лис Б.А. Місцеве самоврядування: сучасний стан та перспективи розвитку / Б.А. Лис [Електронний ресурс]. Режим доступу : http://www.rusnauka.com/7_NMIW_2009/Economics/42124.doc.htm.

6. Серьогін С.M. Теоретичні основи і основні напрямки реформування місцевого самоврядування i децентралізації влади в Україні / C.M. Серьогін, Н.T. Гончарук [Електронний ресурс]. - Режим доступу : http://el-zbirn-du.at.ua/2015_2/29.pdf.

7. Ярошенко I.B. Проблемні питання реалізації реформи децентралізації влади в Україні / I.B. Ярошенко, I.Б. Семигуліна [Електронний ресурс]. - Режим доступу : http://www.problecon.com/export_pdf/problems-ofeconomy-2015-4_0-pages-177_187.pdf.

8. Астапова Т.О. Адаптація зарубіжного досвіду реформування діяльності органів місцевого самоврядування в Україні : автореф. дис. на здобуття наук. ступеня канд. наук з держ. упр. : 25.00 .04 / T.O. Астапова ; Харк. регіон. ін-т держ. упр. НАДУ при Президентові України. - Х., 2010. - 20 с.

9. Методика формування спроможних територіальних громад : Постанова Кабінету Міністрів України від 8 квітня 2015 р. № 214 [Електронний ресурс]. - Режим доступу : https://zakon.rada.gov.ua/laws/show/214-2015-п.

10. Методичні рекомендації щодо формування і реалізації прогнозних та програмних документів соціальноекономічного розвитку об'єднаної територіальної громади : Наказ Міністерства регіонального розвитку, будівництва та житлово-комунального господарства України від 30.03.2016 № 75 [Електронний ресурс]. Режим доступу : https://zakon.rada.gov.ua/rada/show/v0075858-16.

\section{References:}

1. Verhovna Rada Ukrai'ny (2017), Pro misceve samovrjaduvannja v Ukrai'ni, Zakon Ukrai'ny, No. 24, [Online], available at: rada.gov.ua

2. Verhovna Rada Ukrai'ny, Pro miscevi derzhavni administracii', Zakon Ukrai'ny, No. 586-HIV, [Online], available at: rada.gov.ua

3. Gordjejev, O.K. (2012), «Zabezpechennja stalogo miscevogo rozvytku: pidhody, pryncypy, skladovi», Derzhavne budivnyctvo, No. 2, [Online], available at: http://www.kbuapa.kharkov.ua/e-book/db/2012-2/doc/4/04.pdf

4. Zabezpechennja systemnogo pidhodu do reformuvannja administratyvno-terytorial'nogo ustroju, [Online], available at: http://www.niss.gov.ua/public/File/2015_analit/reformaATU.pdf

5. Lys B.A., Misceve samovrjaduvannja: suchasnyj stan ta perspektyvy rozvytku, [Online], available at: http://www.rusnauka.com/7_NMIW_2009/Economics/42124.doc.htm

6. Ser'ogin, S.M. and Goncharuk, N.T., Teoretychni osnovy $i$ osnovni naprjamky reformuvannja miscevogo samovrjaduvannja i decentralizacii' vlady v Ukrai'ni, [Online], available at: http://el-zbirn-du.at.ua/2015_2/29.pdf

7. Jaroshenko, I.V. and Semygulina, I.B., Problemni pytannja realizacii' reformy decentralizacii' vlady $v$ Ukrai'ni, [Online], available at: http://www.problecon.com/export_pdf/problems-of-economy-2015-4_0-pages-177_187.pdf

8. Astapova, T.O. (2010), Adaptacija zarubizhnogo dosvidu reformuvannja dijal'nosti organiv miscevogo samovrjaduvannja v Ukrai'ni, abstract of Ph.D. dissertation, 25.00.04, Hark. region. in-t derzh. upr. NADU pry Prezydentovi Ukrai'ny, H., 20 p.

9. Kabinet Ministriv Ukrai'ny (2015), Metodyka formuvannja spromozhnyh terytorial'nyh gromad, Postanova, No. 214, [Online], available at: https://zakon.rada.gov.ua/laws/show/214-2015-p

10. Ministerstvo regional'nogo rozvytku, budivnyctva ta zhytlovo-komunal'nogo gospodarstva Ukrai'ny (2016), Metodychni rekomendacii' shhodo formuvannja i realizacii' prognoznyh ta programnyh dokumentiv social'noekonomichnogo rozvytku ob'jednanoi' terytorial'noi' gromady, Nakaz, No. 75, [Online], available at: https://zakon.rada.gov.ua/rada/show/v0075858-16

Руденко Наталія Олексіївна - магістрант 1 курсу, гр. ЗДУМ-18-6м, ФПУП Державного університету «Житомирська політехніка».

E-mail: ruden-1980@ukr.net.

Наукові інтереси:

- децентралізація влади;

- об'єднані територіальні громади. 